\title{
Beak Trimming by Infrared Radiation of Layers
}

\section{-Author(s)}

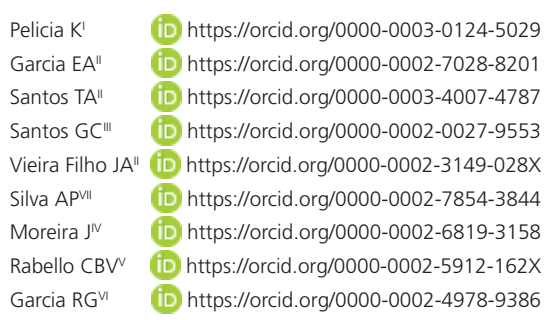

State University of Mato Grosso - Dept. of Animal Science, C.P. 181 - 78250-000 - Pontes e Lacerda, MT, Brazil.

" State University of São Paulo - Dept. of Animal Production, C.P. 560 - 18618-000 - Botucatu, SP, Brazil.

III Federal University of West Pará - Dept. of Animal Science, Vera Paz, s/n - 68035-110 - Santarém, PA, Brazil.

v Federal University of Vale of Jequitinhonha and Mucuri - Dept. of Animal Science, C.P. 34 39100-000 - Diamantina, MG, Brazil.

Rural Federal University of Pernambuco - Dept. of Animal Science, Dom Manoel de Medeiros, s/n 52171-900 - Recife, PE, Brazil.

vi Federal University of Grande Dourados - Dept. of Animal Science, C.P. 533 - 79804-970 Diamantina, MG, Brazil.

VII Lohmann do Brasil, CEP 15020-360 São José do Rio Preto, SP, Brazil.

\section{Mail Address}

Corresponding author e-mail address Kleber Pelicia

Universidade do Estado de Mato Grosso - UNEMAT - Prof. Adjunto do Departamento de Zootecnia - DZO Campus Universitário de Pontes e Lacerda - MT - Brazil.

Phone: (5565) 3266-8123

Email: Kleber.pelicia@unemat.br

\section{- Keywords}

Alternative beak-trimming methods; beaktrimming; infrared radiation; Lohmann White layers.

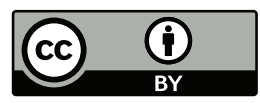

Submitted: 25/November/2017 Approved: 08/March/2018

\section{ABSTRACT}

This study aimed at evaluating beak-trimming methods and intensities on the performance, beak length and uniformity, and egg parameters of commercial layers. During the rearing period, birds were distributed in randomized blocks, with a $2 \times 3$ factorial design + two treatments, consisting of beak trimming with infrared (IR) radiation (moderate or severe); three IR intensities (low: $42 \mathrm{~nm}$, intermediate: 46 $\mathrm{nm}$, or high: $52 \mathrm{~nm}$ ); and two control hot blade (HB) beak trimming treatments (moderate or severe) with eight treatments and five replicates of 21 chicks each, totaling 840 birds. During the growing phase (second experiment) the factorial design was modified to $2 \times$ $3 \times 2+4$, comprising two IR beak-trimming intensities (moderate or severe); three IR radiation intensities (low, moderate and high), second beak trimming at 11 weeks of age or not, and four additional HB beaktrimming treatments (moderate or severe) beak-trimming intensities, and second beak trimming at 11 weeks of age or not. There were 16 treatments with six replicates of seven birds each, totaling 672 laying hens, out of which 576 were selected for evaluation during the production period, with the same number of treatments and replicates of the previous phase. Weight gain (g), body weight (g), body weight uniformity (\%), beak length $(\mathrm{mm})$ and uniformity (\%), absence of cannibalism (\%), livability (\%), egg production (\%), feed intake (g), feed conversion per eggmass, eggmass, specific gravity, eggshell strength, Haugh unit, \% yolk were evaluated. Beak trimming by infrared radiation may be employed in commercial laying hens.

\section{INTRODUCTION}

Productivity indexes in the production of commercial eggs are affected by hen social hierarchy, and when hens are housed in high densities, aggression and cannibalism may occur, as reported by Araújo et al. (2005). Aggression is perhaps one of the most severe animal welfare problems and may cause significant economic losses due to cannibalism and high mortality rates (Rocha et al., 2008).

According to Carruthers et al. (2012) and Damme \& Urselmans (2013), beak trimming is the most efficient method to control cannibalism and lesions caused by to aggressive pecking and feather plucking. Beak trimming may also allow less selectivity of the diet ingredients by the birds and reduce feed waste, resulting in better feed conversion ratio and lower egg production loss due to pecking (Prescott \& Bonser, 2004). However, conventional beak trimming using hot blade (HB) has raised public animal welfare concerns. Despite the performance benefits mentioned above, conventional beak trimming using hot blade $(\mathrm{HB})$ has raised public animal welfare concerns, as this method causes beak tissue damage, with inflammation and sensitivity, 
causing pain upon contact with the house equipment and feed (Fahey et al., 2007; Dennis et al., 2009).

In this context, the scientific community has researched less aggressive beak-trimming methods as alternatives to the $H B$, such as natural wear of the beak tip and the use infrared radiation (IR). This method is based on exposure of the corneous tissue of tip of the beak to infrared light, promoting the gradual softening and erosion of the treated area in the beak, and consequently, providing time for the bird to adapt to changes in beak size and shape. In addition, IR beak trimming does not cause open wounds or hemorrhages as opposed to the HB method (Marchant-Forde et al., 2008; Angevaare et al., 2012).

The objective of this study was to evaluate the effects of beak trimming using infrared radiation (IR) or hot blade (HB) on the performance and egg quality of Lohmann LSL White layers between 17 and 67 weeks of age.

\section{MATERIALS AND METHODS}

\section{Location}

The experiment was conducted at the experimental facilities of the Poultry Sector of the School of Veterinary Medicine and Animal Science, Universidade Estadual Paulista (UNESP), Botucatu campus ( $22^{\circ} 51$ 'S latitude, $48^{\circ} 26^{\prime}$ W longitude, and 786m altitude), SP, Brazil.

All procedures were approved by the Ethics Committee on the Use of Animals in Experiments (Protocol n. 236/ 2012).

\section{Experimental design}

A total number of 576 Lohmann LSL White ${ }^{\circledR}$ layers were evaluated from 17 to 67 weeks of age.

These layers derived from a previous experiment, in which they were submitted at hatch to a randomized design in a $(2 \times 3)+2$ factorial arrangement. The treatments consisted of beak-trimming by IR radiation, maintaining $3 \pm 0.4 \mathrm{~mm}$ (moderate) or $2 \pm 0.4 \mathrm{~mm}$ (severe) of the beak length, three IR radiation intensities (low: $42 \mathrm{~nm}$, intermediate: $46 \mathrm{~nm}$, or high: $52 \mathrm{~nm}$ ) and two control treatments, consisting of moderate $(4.2 \pm 0.2$ beak length) or severe $(1.8 \pm 0.2 \mathrm{~mm}$ beak length) conventional beak trimming by hot blade at six days of age.

Treatments T1, T2 and T3 corresponded to moderate beak-trimming at IR intensities of 42,46 and $52 \mathrm{~nm}$, treatments T4, T5 and T6to severe beak-trimming with IR intensity using IR intensities of 42,46 and $52 \mathrm{~nm}$, and treatments $\mathrm{T} 7$ and $\mathrm{T} 8$ corresponded to moderate and severe HB beak trimming at six days of age with the same treatments after weaning up to 11 weeks. At 11 weeks of age, $50 \%$ of the birds of each treatment were submitted to a second severe beak trimming ( $4 \pm 0.4 \mathrm{~mm}$ beak length) using the same method and IR intensities (Table 1).

During the growing phase (six to 16 weeks age), an experimental design in a $2 \times 3 \times 2+4$ factorial arrangement was applied, consisting of two beak trimmings by IR radiation (moderate and severe); three IR intensities (low: $42 \mathrm{~nm}$, intermediate: $46 \mathrm{~nm}$, or high: $52 \mathrm{~nm}$ ); submitted or not to a second beak trimming;

Table 1 - Beak trimming methods applied to laying hens

\begin{tabular}{|c|c|c|c|c|c|c|c|c|}
\hline & \multicolumn{6}{|c|}{${ }^{*}$ Beak trimming by $\mathbb{I R}$} & \multicolumn{2}{|c|}{${ }^{*}$ Beak trimming by hot blade } \\
\hline & \multicolumn{3}{|c|}{ Moderate } & \multicolumn{3}{|c|}{ Severe } & Moderate & Severe \\
\hline & \multicolumn{3}{|c|}{ IR Intensities (nm) } & \multicolumn{3}{|c|}{ IR Intensities (nm) } & - & - \\
\hline & 42 & 46 & 52 & 42 & 46 & 52 & - & - \\
\hline Treatments Without SBT & T1 & $\mathrm{T} 2$ & T3 & $\mathrm{T} 4$ & T5 & T6 & $\mathrm{T} 7$ & T8 \\
\hline Treatments With SBT & T9 & T10 & T11 & T12 & T13 & T14 & T15 & T16 \\
\hline
\end{tabular}

and four additional treatments: conventional $\mathrm{HB}$ beak trimming at 6 days of age, moderate or severe, submitted or not to beak trimming at 11 weeks of age. Therefore, the number of treatments doubled, from eight to 16, until layers were 67 weeks old (production).

IR beak trimming treatments were applied at hatch in the hatchery using a Poultry Service Processor (PSP), supplied with interface plates $2523^{-1}$ or $2723^{-1} \mathrm{~mm}$ in length and height, which define beak trimming intensity (moderate or severe). Trimmer Lyon ${ }^{\circledR} 50$ 60-1 Hertz and 70-210 watts was employed for HB conventional beak trimming, with precise cuttings, with standard blade surfaces controlling moderate and severe trimmings.

\section{Production phase (17 - 67 weeks)}

At 17 weeks of age, 576 pullets submitted to the treatments described above were selected for the 
Pelicia K, Garcia EA, Santos TA, Santos GC, Vieira Filho JA, Silva AP, Moreira J, Rabello CB, Garcia RG evaluation of performance and egg quality parameters during the production phase. They were divided into 10 treatments with six replicates of six birds each, totaling 96 experimental units.

\section{Experimental management and parame- ters evaluated}

Layers were housed in $50-\mathrm{cm}$ long $x 45 \mathrm{~cm}$ deep $x$ 45-cm high cages, arranged in two rows separated by a service aisle. Six hens were housed in each experimental unit at a density of $375 \mathrm{~cm}^{2}$ hen-1. $^{-1}$. Trough drinkers and feeders were located in front of the cages.

Feeds and management applied during the entire experimental period were based on the handbook published by Lohmann do Brasil ${ }^{\circledR}$ (2011).

The following performance and egg quality parameters were measured: body weight (g) and weight uniformity (\%); beak length $(\mathrm{mm})$ and uniformity $(\%)$; absence of cannibalism rate (\%); livability (\%); egg production (\%); feed intake (g); feed conversion ratio per egg mass; egg mass (g); egg specific gravity; eggshell breaking strength (kgf); Haugh units (HU); yolk (\%).Average treatment results were weekly evaluated during the 17-67 week period, except for BW and BW uniformity, which were evaluated every two weeks from 18 weeks of age.

Cannibalism was defined as birds presenting tears in the skin and adjacent tissues as a result of pecking by other birds. Absence of cannibalism rate was calculated as the total number of birds per treatment minus the number of cannibalized individuals and expressed as a percentage relative to the total number of birds per treatment.

Body weight and BW uniformity were determined during the production phase. Body weight uniformity, and beak length and uniformity were measured in two replicates/treatment. Birds were individually weighed on a digital scale. Beak length was measured from the nostril using a digital caliper $(0-150 \mathrm{~mm}$ at $0.01-\mathrm{mm}$ precision).

Body weight uniformity was determined as a function of average body weight, calculated as the sum of the BW of all birds divided by the total number of birds in each treatment. Upper and lower limits were calculated by adding or subtracting $10 \%$ from the average BW, respectively. The number of birds within the upper and lower limits were counted, and expressed as a percentage of the total number of birds in each treatment.

Beak length $(\mathrm{mm})$ was measured from the nostril, as proposed by Kuenzel (2007), at 3, 6, 10, 13, 17,
20, 34 days of age, 10 weeks of age, after the second beak trimming, and at 16 weeks of age, using a digital caliper (Mitotoyo 0-150mm, 0.01-mm accuracy). In the treatments using IR radiation, the number of days between beak trimming and beak detachment beak was recorded.

Egg production percentage was calculated by dividing the average number of eggs produced per bird weekly by the average number of birds multiplied by seven, and the result was multiplied by 100 .

Average egg weight was calculated at total weekly egg weight by weekly egg number and the result expressed in grams.

Egg mass was obtained by multiplying average egg weight by egg production percentage, and dividing the result by 100. Egg mass is expressed in grams of eggs per bird per day.

The feed conversion ratio per egg mass was calculated by dividing total feed intake $(\mathrm{kg})$ per replicate by total weight $(\mathrm{kg})$ of the eggs laid during the same period.

Eggshell quality and internal egg contents were evaluated every 28 days. Two eggs per cage (12 eggs/ treatment) were collected for three consecutive days for analyses.

Eggshell strength was evaluated using a specific cell coupled to a Texture Analyser TA. XT with a 2-mm stainless Cylprobe, code $P 2^{-1}$, pre-test speed of $2 \mathrm{~mm}$ second $^{-1}$; test speed of $1.0 \mathrm{~mm} \mathrm{~second}^{-1}$ and posttest speed of $40 \mathrm{~mm} \mathrm{~second}^{-1}$, to determine eggshell breaking strength, in kgf.

Data were submitted to analysis of variance (ANOVA) using SAEG (Analysis System of Statistics and Genetics, 9.1). When the F-test yielded significant results $(p<0.05)$, means were compared by the test of Tukey. Additional comparisons of means between beak-trimming intensity (moderate and severe) in IR and $\mathrm{HB}$ treatments were applied after the factorial solution. Percentage data were transformed into [ $\mathrm{x}$ $+0.5) \wedge 0.5]$ to reduce data heterogeneity in further analyses.

\section{RESULTS AND DISCUSSION}

Table 2 shows beak length and uniformity, absence of cannibalism and livability results. No effects of IR intensity $(p>0.05)$ on any of these parameters were detected.

There was an interaction $(p=0.00)$ in IR treatment between moderate and severe beak-trimming intensity and second beak trimming at 11 weeks of 
Table 2 - Body weight (g), body weight uniformity (\%); beak length ( $\mathrm{mm})$, beak uniformity (\%); absence of cannibalism (\%), and livability (\%) means of Lohmann LSL laying hens between 17 and 67 weeks of age, submitted to moderate or severe beak trimming by infrared (IR) or hot blade (HB) only at hatch (1x) or at hatch and 11 weeks of age (2x).

\begin{tabular}{|c|c|c|c|c|c|c|c|c|}
\hline \multirow{3}{*}{ Intensity } & \multicolumn{8}{|c|}{ Beak-trimming method } \\
\hline & \multicolumn{2}{|l|}{ Infrared $^{1}$} & \multicolumn{2}{|c|}{ Hot blade ${ }^{2}$} & \multicolumn{2}{|l|}{ Infrared ${ }^{1}$} & \multicolumn{2}{|c|}{ Hot blade $^{2}$} \\
\hline & \multicolumn{4}{|c|}{ Body weight after 18 weeks $(\mathrm{kg})$} & \multicolumn{4}{|c|}{ Body weight uniformity (\%) } \\
\hline $1 \mathrm{x}$ & \multicolumn{3}{|c|}{ Mean } & Mean & \multicolumn{3}{|c|}{ Mean } & Mean \\
\hline Moderate & $1.42 A^{*}$ & \multirow{2}{*}{$1.42 \mathrm{~A} * \mathrm{a}$} & $1.40 \mathrm{E}$ & \multirow{2}{*}{$1.39 \mathrm{Ab}$} & 84 & \multirow{2}{*}{83} & 79 & \multirow{2}{*}{80} \\
\hline Severe & $1.41 A^{*} a$ & & 1.37 Eb & & 82 & & 84 & \\
\hline \multicolumn{9}{|l|}{$2 x$} \\
\hline Moderate & $1.25 \mathrm{~B} * a$ & \multirow{3}{*}{$1.27 B^{*}$} & $1.29 \mathrm{Fb}$ & \multirow{3}{*}{$1.28 \mathrm{~B}$} & 77 & \multirow{3}{*}{77} & 76 & \multirow{3}{*}{75} \\
\hline Severe & $1.29 A^{*}$ & & $1.27 \mathrm{~F}$ & & 77 & & 75 & \\
\hline Mean & 1.35 & & 1.33 & & 80 & & 77 & \\
\hline CV (\%) & \multicolumn{3}{|c|}{3.02} & & \multicolumn{4}{|c|}{9.60} \\
\hline & \multicolumn{3}{|c|}{ Beak length $(\mathrm{mm})$} & & \multicolumn{3}{|c|}{ Beak uniformity (\%) } & \\
\hline $1 \mathrm{x}$ & \multicolumn{3}{|c|}{ Mean } & Mean & \multicolumn{3}{|c|}{ Mean } & Mean \\
\hline Moderate & $13.3 A * b$ & \multirow{2}{*}{$12.4 A^{*}$} & 14.6 Ea & \multirow{2}{*}{$12.6 \mathrm{~A}$} & $95 \mathrm{~A}$ & \multirow{2}{*}{$92 \mathrm{~A}$} & $90 \mathrm{E}$ & \multirow{2}{*}{$90 \mathrm{~A}$} \\
\hline Severe & $11.5 \mathrm{~B} * \mathrm{a}$ & & $10.5 \mathrm{Fb}$ & & $88 \mathrm{~A}$ & & $90 \mathrm{E}$ & \\
\hline \multicolumn{9}{|l|}{$2 x$} \\
\hline Moderate & $6.0 B^{*}$ & & $6.4 \mathrm{H}$ & & $86 A B$ & & $72 \mathrm{G}$ & \\
\hline Severe & $6.4 A^{*} b$ & $6.2 \mathrm{~B} * \mathrm{~b}$ & $6.9 \mathrm{Ga}$ & 6.7 Ba & $78 \mathrm{~B}$ & $82 \mathrm{~B}$ & $82 \mathrm{~F}$ & $77 \mathrm{~B}$ \\
\hline Mean & $9.3 \mathrm{~b}$ & & $9.7 \mathrm{a}$ & & 87 & & 84 & \\
\hline CV (\%) & & & & & & & & \\
\hline & & bsence of & lism (\%) & & & ability & & \\
\hline $1 x$ & & Mean & & Mean & & Mean & & Mean \\
\hline Moderate & $98.3 \mathrm{a}$ & & $91.6 \mathrm{Fb}$ & $058 \mathrm{~h}$ & $99.4 \mathrm{a}$ & & $95.5 \mathrm{Fb}$ & \\
\hline Severe & 98.3 & $98.3 \mathrm{a}$ & $100.0 \mathrm{E}$ & $95.8 \mathrm{~b}$ & 98.8 & $99.1 \mathrm{a}$ & $99.4 \mathrm{E}$ & $97.5 \mathrm{~b}$ \\
\hline $2 x$ & & & & & & & & \\
\hline Moderate & $99.4 \mathrm{a}$ & & $98.8 \mathrm{~Eb}$ & & 98.3 & & $98.3 \mathrm{E}$ & \\
\hline Severe & 100.0 & 99.2 & $100.0 \mathrm{E}$ & 99.4 & 98.3 & 98.3 & $98.8 \mathrm{E}$ & 98.6 \\
\hline Mean & 99.1 & & 97.5 & & 98.7 & & 98.0 & \\
\hline CV (\%) & & 2.04 & & & & & & \\
\hline
\end{tabular}

${ }^{1}$ As there were no effects of IR light intensity ( $\left.p>0.05\right)$, only beak-trimming intensity means (moderate and severe) are given. Means followed by letters with asterisk ( ${ }^{*}$, $\left.B^{*}\right)$ indicate interaction $(p<0.05)$ between beak-trimming method and intensity, with and without second trimming. Means followed by uppercase letters in the same column $(A, B)$ and lowercase letters in the same row line $(a, b)$ differ by $F$ test at $p<0.05$. $^{2}$ For hot blade beak-trimming, means followed by capital letters ( $\left.E, F, G, H\right)$ in the same column differ by Tukey's multiple comparison test at $p<0.05$. CV (\%): coefficient of variation.

age for beak length measured at 11 weeks of age. The interaction revealed that layers submitted to severe IR beak trimming only once (T12, T13, T14) had longer beaks than those submitted to moderate IR and to a second beak trimming (T9, T10, T11) from one day to six weeks of age. A similar behavior was determined for $\mathrm{HB}$, where longer beaks were measured in birds submitted to severe HB beak trimming (T12; T13; T14) once than in those submitted to moderate HB beak trimming (T9; T10; T11) twice-trimmed birds with severe intensity 11 weeks of age had a greater beak length when submitted to second trimming.

\section{Comparison among treatments of layers submitted to beak trimming once}

Body weight uniformity was not influenced ( $p>0.05$ ) by beak trimming methods or intensities.
When moderate beak trimming was applied, no BW, BW uniformity or beak uniformity differences ( $p>0.05$ ) between IR or HB were detected. However, moderate beak trimming by IR trimming resulted in shorter beaks and higher absence cannibalism and livability compared with HB trimming. When severe beak trimming was applied, IR-trimmed birds presented longer and higher BW compared to HB-trimmed birds $(p<0.05)$.

When birds were submitted to IR beak trimming, trimming intensity did not influence BW, BW uniformity or beak uniformity. However, moderate IR beaktrimmed birds had longer beaks and higher absence of cannibalism and livability than those severely beaktrimmed ( $p>0.05)$.

Comparing $\mathrm{HB}$ beak-trimming intensities, no BW, BW uniformity or beak uniformity differences $(p>0.05)$ were detected, but birds submitted to moderate HB 


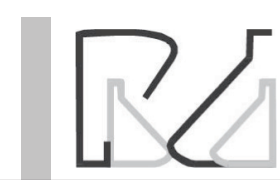

beak trimming presented longer beak and lower absence of cannibalism and lower livability when compared with those submitted to severe HB beak trimming.

\section{Comparison among treatments of layers submitted to beak trimming twice}

No effects of beak-trimming methods on beak uniformity were detected ( $p>0.05$ ).

When birds were submitted to moderate beak trimming, IR resulted in lower BW, lower cannibalism rate and higher livability than $\mathrm{HB}$. In the case of severe beak trimming, shorter beaks were determined in IR beak-trimmed birds than those beak-trimmed by HB, but there were no differences were found for the other evaluated parameters.

No BW uniformity, beak uniformity, absence of cannibalism and livability differences were determined when results of moderate and severe IR beak trimming were analyzed. However, moderate IR resulted in shorter beaks and lower beak uniformity compared with severe HB beak trimming, but the other characteristics were not affected by IR and HB treatments.

The comparison between birds submitted to beak trimming once or twice showed that those submitted to beak trimming twice presented lower BW weight and shorter and less uniform beaks, but no differences in BW uniformity, absence of cannibalism rate or livability compared with birds beak-trimmed once.

Comparing the general average of $I R$ and $H B$ treatments, only beak length was affected. Birds beak-trimmed by IR had shorter beaks compared with those trimmed by $\mathrm{HB}$, but this difference did not cause any significant effects on BE, BW uniformity, beak uniformity, absence of cannibalism rate or livability. The results are consistent with those reported by Dennis \& Cheng (2012), who found statistically similar BW in 20-week-old laying hens beak-trimmed by IR and HB. However, several previous studies reported reduced body development and body weight after hot-blade beak trimming (Blokhuis et al., 1987; Glatz \& Lunam, 1994; Glatz, 2005) found that birds submitted to laser beak trimming presented higher body weight after 14 days of age in comparison with the use of hot blade. In the present experiment, no weight gain differences were found, although birds beak-trimmed by IR had shorter beaks compared with those trimmed by HB.

In a comparative study between IR and HB beak trimming, Marchant-Forde \& Cheng (2010) reported an interaction between beak-trimming treatment and beak regeneration time, with longer beaks in birds treated by HB when compared to IR beak treatment, but that the efficiency of IR beak trimming to inhibit beak regeneration rate is not known. However, Dennis \& Cheng (2010), evaluating laser trimming of layers, found better feed efficiency due beak anatomy after trimming. Laser-trimmed beaks were longer and more symmetrical than hot blade-trimmed beaks, and were less sensitive to pain during feeding, minimizing the negative effects of beak trimming.

Lower absence of cannibalism rate was determined in moderate IR beak-trimmed birds. Rates higher than $8 \%$ were obtained when the accumulated period of 1-26 weeks of age was taken into account. According to Gentle \& Mckeegan (2007) and Carruthers et al. (2012) beak length is associated with aggressive behavior levels and, although severe beak trimming may affect bird performance and welfare, mild beak trimming allows fast beak regeneration and is less efficient in the prevention of cannibalism.

Beak-trimming method may increase stress and impair immune functions and livability (Table 2), as previously reported by Xie et al. (2013). The results of the present experiment agree with the findings of Dennis et al. (2009), who compared IR with HB beak trimming and reported an increase in cannibalism in 1to 30-week-old laying hens beak-trimmed using HB.

Petrolli et al. (2017) observed that pullets submitted to laser beak trimming presented higher body weight at all evaluated ages relative to hot-blade beak trimming. Short-beaked birds had a higher body weight than those with long beaks, as reported by Henderson et al. (2009) in broiler breeders, differently from the present experiment, where birds submitted to the second beak trimming showed shorter beak and lower body weight. However, in the study of Henderson et al. (2009), longer beak length was preserved than in the present study. The short beak length analyzed in the present study, particularly after the second trimming, may have caused higher beak sensitiveness, as reported by Gentle et al. (1997 a, b) and Swayne (2003), resulting in lower feed intake (Table 3) and, consequently, lower body weight.

In the present experiment, layers submitted to both beak-trimming methods applied presented higher BW at 18 weeks of age compared with the recommendations of the management manual (Lohmann do Brasil@ 2011), of 1.17 kg body weight.

Table 3 shows the results of egg production (\%), feed intake (g), average egg weight(g) and feed conversion ratio per eggmass $\left(F C R ; g^{-1}\right)$. 
Table 3 - Egg production (\%), feed intake (g), average egg weight (g), egg mass (g), feed conversion ratio per egg mass ( $\mathrm{g}$ $\mathrm{g}^{-1}$ ) means of Lohmann LSL laying hens between 17 and 67 weeks old, submitted to moderate or severe beak trimming by IR or HB only at hatch $(1 \mathrm{x})$ or at hatch and 11 weeks of age $(2 \mathrm{x})$.

\begin{tabular}{|c|c|c|c|c|c|c|c|c|}
\hline \multirow[b]{2}{*}{ Intensity } & \multicolumn{8}{|c|}{ Beak-trimming method } \\
\hline & \multicolumn{2}{|l|}{ Infrared ${ }^{1}$} & \multicolumn{2}{|c|}{ Hot blade $^{2}$} & \multicolumn{2}{|c|}{ Infrared $^{1}$} & \multicolumn{2}{|c|}{ Hot blade $^{2}$} \\
\hline & \multicolumn{4}{|c|}{ Egg production (\%/) } & \multicolumn{4}{|c|}{ Feed intake $\left(\mathrm{g} \mathrm{hen}^{-1} \mathrm{day}^{-1}\right)$} \\
\hline $1 x$ & & Mean & & Mean & & Mean & & Mean \\
\hline Moderate & 88.37 & \multirow{2}{*}{88.18} & 88.69 & \multirow{2}{*}{88.35} & $129.23 b$ & \multirow{2}{*}{$130.65 \mathrm{~A}$} & $144.87 a$ & \multirow{2}{*}{$138.39 \mathrm{~A}$} \\
\hline Severe & 87.98 & & 88.00 & & 132.07 & & 131.90 & \\
\hline \multicolumn{9}{|l|}{$2 \mathrm{x}$} \\
\hline Moderate & 88.00 & \multirow{3}{*}{88.62} & 88.20 & \multirow{3}{*}{88.36} & 126.40 & \multirow{3}{*}{$126.13 B$} & 124.28 & \multirow{3}{*}{$125.96 \mathrm{~B}$} \\
\hline Severe & 89.23 & & 88.52 & & 125.86 & & 127.63 & \\
\hline \multirow[t]{2}{*}{ Mean } & 88.40 & & 88.35 & & 128.39 & & 132.17 & \\
\hline & \multicolumn{4}{|c|}{ Eggmass (g) } & \multicolumn{4}{|c|}{ Feed conversion per eggmass $\left(\mathrm{g} \mathrm{g}^{-1}\right)$} \\
\hline $1 x$ & \multicolumn{3}{|c|}{ Mean } & Mean & \multicolumn{3}{|c|}{ Mean } & Mean \\
\hline Moderate & 53.74 & \multirow{3}{*}{53.68} & 52.37 & \multirow{3}{*}{52.97} & $2.40 \mathrm{~b}$ & \multirow{3}{*}{$2.43 \mathrm{~A}$} & $2.77 a$ & \multirow{3}{*}{$2.61 \mathrm{~A}$} \\
\hline Severe & 53.60 & & 53.55 & & 2.46 & & 2.46 & \\
\hline \multicolumn{5}{|l|}{$2 x$} & & & & \\
\hline Moderate & 53.31 & \multirow{3}{*}{53.46} & 53.96 & \multirow{3}{*}{53.77} & 2.37 & \multirow{3}{*}{$2.36 \mathrm{~B}$} & 2.30 & \multirow{3}{*}{$2.34 \mathrm{~B}$} \\
\hline Severe & 53.61 & & 53.58 & & 2.35 & & 2.38 & \\
\hline Mean & 53.57 & & 53.37 & & 2.40 & & 2.47 & \\
\hline
\end{tabular}

${ }^{1}$ As there were no effects of IR light intensity ( $p>0.05$ ), only beak-trimming intensity means (moderate and severe) are given. Means followed by uppercase letters in the same column $(A, B)$ and lowercase letters in the same row line $(a, b)$ differ by $F$ test at $p<0.05$. CV $(\%)$ : coefficient of variation.

There was no interaction between the analyzed factors when birds were submitted to IR beak trimming. There was no effect of IR intensities on the evaluated characteristics. However, birds submitted to IR beak trimming twice presented higher feed intake and better feed conversion ratio per eggmass $\left(\mathrm{g} \mathrm{g}^{-1}\right)$ than those beak-trimmed by IR once.

\section{Comparison among treatments of layers submitted to beak trimming once}

Egg production, average egg weight, and egg mass were not influenced ( $p>0.05$ ) by beak-trimming method or intensity, as shown in Table 2 .

When moderate beak trimming was applied, IRtrimmed birds presented lower feed intake and better FCR compared with HB-trimmed birds, but no feed intake or FCR differences were detected when birds were submitted to severe IR or HB beak trimming.

\section{Comparison among treatments of layers submitted to beak trimming twice}

There was no effect of beak trimming intensity or method on egg production, average egg weight, egg mass, feed intake or FCR ( $p>0.05)$ of layers submitted to beak trimming twice.

When comparing the results of layers submitted to beak trimming once or twice, the evaluated treatments did not influence ( $p>0.05)$ egg production, average egg weight or egg mass. However, birds beak-trimmed twice presented lower feed intake and better FCR than those trimmed once.

Moderate IR beak trimming resulted lower feed intake compared with moderate HB beak trimming. This FI reduction may be explained by less feed wasting caused by short beaks (Table 1). Similarly, a shorter beak was observed when severe IR beak trimming was applied twice, resulting in better feed conversion when compared with severe $\mathrm{HB}$ beak trimming.

Better FCR was obtained in birds submitted to severe IR beak trimming than in those submitted to moderate IR beak trimming, which may be due to a shorter beak after the second severe beak trimming compared with HB-beak trimmed birds (Table 2).

During the period between 18 and 67 weeks of age, IR-beak trimmed layers presented $88.40 \%$ egg production, $60.60 \mathrm{~g}$ average egg weight and 53.57 $\mathrm{g}$ eggmass, whereas $\mathrm{HB}$ beak trimming resulted in88.35\% egg production, $60.40 \mathrm{~g}$ average egg weight and $53.37 \mathrm{~g}$ egg mass. IR beak trimming promoted numerically superior performance than the conventional HB-beak trimming method and relative to that recommended by the strain manual (Lohmann do Brasil $^{\circledR}$, 2011), of $86 \%$ egg production, $59.74 \mathrm{~g}$ average egg weight, and $53.1 \mathrm{~g}$ egg mass from 19 to 67 weeks of age.

Differently from our results (Table 3), Jongman et al. (2008) did not find any performance differences between layers beak-trimmed once or twice. In the 
present study, moderate IR beak trimming resulted in lower feed intake and better feed conversion ratio per egg mass than HB moderate beak trimming. Results were due to the influence of beak-trimming method on the immune system and, consequently, on layer performance, as reported by Xie et al. (2013).

Evaluating laser and HB beak-trimming methods, Petrolli et al. (2017) stated that, although both methods allow similar oviduct development, the higher body weight of laser-trimmed layers suggest that they may sustain egg production longer than hot blade-trimmed layers.

Table 4 shows the results of egg specific gravity ( $\left.\mathrm{g} \mathrm{mL}^{-1}\right)$, eggshell strength $(\mathrm{kg})$, Haugh units (\%) and yolk (\%). None of these parameters were statistically influenced by beak-trimming intensity or method in layers submitted to beak trimming once or twice.

Table 4 - Specific gravity ( $\mathrm{g} / \mathrm{mL}$ ), eggshell strength ( $\mathrm{kgf})$, Haugh units (\%) and yolk (\%) of Lohmann LSL laying hens between 17 and 67 weeks old, submitted to moderate or severe beak trimming by IR or HB only at hatch (1x) or at hatch and 11 weeks of age $(2 x)$.

\begin{tabular}{|c|c|c|c|c|c|c|c|c|}
\hline \multirow{3}{*}{ Intensity } & \multicolumn{8}{|c|}{ Beak-trimming method } \\
\hline & \multicolumn{2}{|c|}{ Infrared ${ }^{1}$} & \multicolumn{2}{|c|}{ Hot blade $^{2}$} & \multicolumn{2}{|c|}{ Infrared ${ }^{1}$} & \multicolumn{2}{|c|}{ Hot blade ${ }^{2}$} \\
\hline & \multicolumn{4}{|c|}{ Specific gravity $\left(\mathrm{g} \mathrm{mL}^{-1}\right)$} & \multicolumn{4}{|c|}{ Eggshell strength (kgf) } \\
\hline $1 x$ & & Mean & & Mean & & Mean & & Mean \\
\hline Moderate & 1.089 & \multirow{2}{*}{1.089} & 1.089 & \multirow{2}{*}{1.089} & 3.93 & \multirow{2}{*}{3.96} & 4.26 & \multirow{2}{*}{4.11} \\
\hline Severe & 1.089 & & 1.088 & & 3.98 & & 3.95 & \\
\hline \multicolumn{9}{|l|}{$2 x$} \\
\hline Moderate & 1.088 & \multirow{3}{*}{1.089} & $1.091 \mathrm{~A}$ & \multirow{3}{*}{1.089} & 3.79 & \multirow{3}{*}{3.99} & 4.18 & \multirow{3}{*}{3.91} \\
\hline Severe & 1.089 & & 1.087B & & 4.19 & & 3.63 & \\
\hline \multirow[t]{2}{*}{ Mean } & 89 & & 89 & & & & & \\
\hline & \multicolumn{4}{|c|}{ Haugh units } & \multicolumn{4}{|c|}{ Yolk (\%) } \\
\hline $1 \mathrm{x}$ & \multicolumn{3}{|c|}{ Mean } & Mean & & \multicolumn{2}{|c|}{ Mean } & Mean \\
\hline Moderate & 86.97 & \multirow{2}{*}{87.58} & 88.59 & \multirow{2}{*}{88.01} & 26.89 & \multirow{2}{*}{26.88} & 26.16 & \multirow{2}{*}{26.64} \\
\hline Severe & 88.18 & & 87.43 & & 26.87 & & 27.12 & \\
\hline \multicolumn{9}{|l|}{$2 x$} \\
\hline Moderate & 88.51 & \multirow{3}{*}{88.47} & 82.68 & \multirow{3}{*}{85.48} & 26.45 & \multirow{2}{*}{26.07} & 26.82 & \multirow{3}{*}{26.70} \\
\hline Severe & 88.42 & & 88.28 & & 25.69 & & 26.57 & \\
\hline Mean & 88.02 & & 86.75 & & 26.48 & & 26.67 & \\
\hline
\end{tabular}

${ }^{1}$ As there were no effects of IR light intensity ( $\left.p>0.05\right)$, only beak-trimming intensity means (moderate and severe) are given. Means followed by uppercase letters in the same column $(A, B)$ and lowercase letters in the same row line $(a, b)$ differ by $F$ test at $p<0.05$. CV $(\%)$ : coefficient of variation.

There was no effect ( $p>0.05)$ of beak trimming intensity or method on the measured albumin (\%), eggshell (\%), eggshell thickness (\%) and eggshell percentage per surface area (\%) in layers beak-trimmed once or twice, as shown in Table 5.

It would be expected that that second beaktrimming by LB could have provided less FSH secretion and less calcium in the shell gland, which improved the low-size eggs and low-quality eggshell reported by Miller \& Sunde (1975); Emery et al. (1984); and Mahmoud et al. (1996).

Second severe $\mathrm{HB}$ beak-trimming may have increased layers' stress. According to Tuomisto \& Mannisto (1985) and Pohle (2009), egg weight, eggshell thickness and feed conversion ratio are affected by stress, which causes decrease in corticosterone (CORT) and serotonin (5-HT) concentrations. Those authors report that CORT and $5-\mathrm{HT}$ are stress indicators because they directly and indirectly affect the reproductive performance by linking receptors lying in the central nervous system and reproduction organs in humans and animals, including hens.

The neurotransmitter serotonin controls adaptive and cognitive maintenance and emotional processing as a response to stimulation. Serotonin and its main metabolite, 5-hydroxyindoleacetic acid, are employed as stress indicators in several animals, as reported by Steklis et al. (1986), Raleigh et al. (1991), and Cubitt et al. (2008). Previous studies (Lanfumey et al., 2008) showed that CORT regulates $5-\mathrm{HY}$ function and reduce5-HT plasma levels, indicating hyperactivity of the hypothalamus-hypophysis-adrenal axis to different stress responses, according to Bianchi et al. (2002).

In the present study, layers submitted to IR beaktrimming only at hatch showed higher body weight, lower cannibalism rate, higher livability and feed intake, and better FCR that those beak-trimmed by HB. Higher body weight was obtained in severely IR beak-trimmed 
Table 5 - Albumin (\%), eggshell (\%), eggshell thickness (\%) and eggshell percentage per surface area (ESA\%) of Lohmann LSL laying hens between 17 and 67 weeks old, submitted to moderate or severe beak trimming by IR or HB only at hatch $(1 \mathrm{x})$ or at hatch and 11 weeks of age $(2 \mathrm{x})$.

\begin{tabular}{|c|c|c|c|c|c|c|c|c|}
\hline \multirow{2}{*}{ Intensity } & \multicolumn{8}{|c|}{ Beak-trimming method } \\
\hline & \multicolumn{2}{|l|}{ Infrared ${ }^{1}$} & \multicolumn{2}{|c|}{ Hot blade $^{2}$} & & \multicolumn{3}{|c|}{ Hot blade $^{2}$} \\
\hline \multicolumn{9}{|c|}{ Albumin (\%) } \\
\hline $1 \mathrm{x}$ & \multicolumn{3}{|c|}{ Mean } & \multicolumn{2}{|l|}{ Mean } & \multicolumn{2}{|l|}{ Mean } & Mean \\
\hline Moderate & 63.06 & \multirow{2}{*}{63.12} & 63.60 & \multirow{2}{*}{63.24} & 10.05 & \multirow{2}{*}{10.00} & 9.96 & \multirow{2}{*}{10.03} \\
\hline Severe & 63.10 & & 62.87 & & 10.02 & & 10.09 & \\
\hline \multicolumn{9}{|l|}{$2 x$} \\
\hline Moderate & 63.89 & \multirow{3}{*}{63.87} & 63.16 & \multirow{3}{*}{63.42} & 9.66 & \multirow{3}{*}{9.82} & 10.02 & \multirow{3}{*}{9.89} \\
\hline Severe & 63.84 & & 63.68 & & 9.97 & & 9.76 & \\
\hline \multirow[t]{2}{*}{ Mean } & 63.47 & & 63.33 & & & & & \\
\hline & & \multicolumn{4}{|c|}{ Eggshellthickness (mm) } & \multicolumn{3}{|c|}{ ESA $\left(m g\left(\mathrm{~cm}^{2}\right)^{-1}\right)$} \\
\hline $1 \mathrm{x}$ & & \multicolumn{2}{|c|}{ Mean } & \multicolumn{2}{|l|}{ Mean } & \multicolumn{2}{|c|}{ Mean } & Mean \\
\hline Moderate & 0.51 & \multirow{3}{*}{0.50} & 0.49 & \multirow{3}{*}{0.49} & 84.39 & \multirow{3}{*}{84.39} & 83.69 & \multirow{2}{*}{83.59} \\
\hline Severe & 0.50 & & 0.49 & & 84.31 & & 83.51 & \\
\hline \multicolumn{6}{|l|}{$2 x$} & & & \\
\hline Moderate & 0.50 & \multirow{3}{*}{0.50} & 0.49 & \multirow{3}{*}{0.49} & 81.51 & \multirow{3}{*}{82.71} & 84.69 & \multirow{3}{*}{83.01} \\
\hline Severe & 0.51 & & 0.50 & & 83.79 & & 81.21 & \\
\hline Mean & 0.50 & & 0.49 & & 83.50 & & 83.30 & \\
\hline
\end{tabular}

'As there were no effects of IR light intensity $(p>0.05$ ), only beak-trimming intensity means (moderate and severe) are given. Means followed by uppercase letters in the same column $(\mathrm{A}, \mathrm{B})$ and lowercase letters in the same row line $(\mathrm{a}, \mathrm{b})$ differ by $\mathrm{F}$ test at $p<0.05$. CV $(\%)$ : coefficient of variation.

layers only at hatch than in those beak-trimmed by $H B$. This suggests that beak-trimming by IR only at hatch may replace conventional beak-trimming by HB. Layers submitted to beak trimming twice presented lower body weight than those beak-trimmed only hatch, despite showing lower feed intake and better FCR independently of the method. Therefore, a second beak trimming is recommended.

When beak trimming was performed twice, moderate IR caused a decrease in body weight compared with moderate HB; however, it was close to that recommended by the strain handbook. The layers that were IR beak-trimmed once tended to show less cannibalism and higher livability independently of the intensity without SBT. When layers were beak-trimmed twice, moderate IR resulted in lower body weight at 18 weeks of age compared with severe IR, but were close to the body weight recommended in the strain handbook. It should be highlighted that when the second beak trimming was applied, moderate HB method promoted higher egg specific gravity that the severe HB method. When a second beak trimming is applied, the IR method may replace the conventional HB method, or to apply moderate HB.

When IR and HB treatments are contrasted, no effect was detected for egg productions, diet intake, average egg weight, feed conversion and egg mass. And also for egg quality no effect on albumin (\%), eggshell (\%), eggshell thickness (\%) and percentage of eggshell per surface area (\%) was registered.

\section{CONCLUSIONS}

Infra-red may be employed for beak trimming commercial laying hens because it does not impair production performance and promote similar egg quality that obtained by conventional hot-blade beak-trimming. In addition, moderate infra-red beaktrimming intensity may be applied as it does not result in considerable differences from severe beak trimming either with hot blade or infrared radiation.

\section{ACKNOWLEDGMENTS}

The authors would like to thank LOHMANN DO BRASIL ${ }^{\circledR}$ and NOVA-TECH ${ }^{\circledR}$ Engineering for their support for the current research study, especially their technical supervisors Anderson de Pontes Silva and Jay Michael Halliday.

\section{REFERENCES}

Angevaare MJ, Prins S, Staay FJV, Nordquist RE. The effect of maternal care and infrared beak trimming on development, performance and behavior of Silver Nick hens. Applied Animal Behaviour Science 2012;140:70-84.

Araújo LF, Café MB, Leandro NSM, Junqueira OM, Araújo CSS, Cunha $M I R$, et al. Desempenho de poedeiras comerciai submetidas ou não a diferentes métodos de debicagem. Ciência Rural 2005;35:169-173. 
Bianchi M, Moser C, Lazzarini C, Vecchiato E, Crespi F. Forced swimming test and fluoxetine treatment: In vivo evidence that peripheral $5-\mathrm{HT}$ in rat platelet-rich plasma mirrors cerebral extracellular 5-HT levels, whilst 5-HT in isolated plate-lets mirrors neuronal 5-HT changes. Experimental Brain Research 2002;143:191-197.

Blokhuis HJ, Van Der Haar JJ, Pgkoole PG. Effects of beak trimming and floor type of feed consumption and body weight of pullets during rearing. Poultry Science 1987;66:623-625.

Carruthers C, Gabrush T, SChwean-Lardner K, Knezacek TD, Classen HL, Bennett $C$. On-farm survey of beak characteristics in White Leghorns as a result of hot blade trimming or infrared beak treatment. Journal Applied Poultry Research 2012;21:645-650.

Cubitt KF, Winberg S, Huntingford FA, Kadri S, Cramp-Ton VO, Overli O. Social hierarchies, growth and brain se-rotonin metabolism in Atlantic salmon (Salmo salar) kept under commercial rearing conditions. Physiology Behavior 2008;94:529-535.

Damme K, Urselmans S. Infrared beak treatment -a temporary solution? [cited 2016 Jan]. Lohmann Information ;2013. Available from: http:// www.lohmann-information.com/content/l_i_48_artikel12.pdf.

Dennis RL, Cheng HW. Effects of different infrared beak treatment protocols on chicken welfare and physiology. Poultry Science 2012;91:14991505.

Dennis RL, Fahey AG, Cheng HW. Infrared beak treatment method compared with conventional hot-blade trimming in laying hens. Poultry Science 2009;88:38-43.

Emery DA, Vohra P, Ernst RA, Morrison SR. The effect of cyclic and constant ambient temperatures on feed consumption, egg production, egg weight, shell thickness of hens. Poultry Science 1984;63:2027-2035.

Fahey G, Marchant-Forde RM, Cheng HW. Relationship between body weight and beak characteristics in one-day-old white leghorn chicks: its implications for beak trimming. Poultry Science 2007;86:1312-1315.

Gentle MJ, Hughes BO, Fox A, Waddington D. Behavioural and anatomical consequences of two beak trimming methods in 1- and 10-d-old domestic chicks. British Poultry Science 1997a;38:453-463.

Gentle MJ, Hunter LN, Corr SA. Effects of caudolateral neostriatal ablations on pain-related behaviour in the chicken. Physiology Behavior 1997b;61:493-498.

Gentle MJ, Mckeegan DEF. Evaluation of the effects of infrared beak trimming in broiler breeder chicks. Veterinary Record 2007;160:145148.

Glatz PC, Lunam CA. Production and heart rate responses of chickens beak-trimmed at hatch at 10 or 42 days-of-age. Australian Journal of Experimental Agriculture 1994;34:443-447.

Glatz PC. What is beak-trimming and why are birds trimmed? In: Glatz PC, editor. Poultry welfare issues: beak trimming. Nottingham: Nottingham University Press; 2005. p.1-17.

Henderson SN, Barton JT, Wolfenden AD, Higgins SE, Higgins JP, Kuenzel WJ, et al. Comparison of beak-trimming methods on early broiler breeder performance. Poultry Science 2009;88:57-60.
Jongman EC, Glatz P, Barnett JL. Changes in behaviour of laying hens following beak trimming at hatch and re-trimming at 14 weeks. AsianAustralasian Journal of Animal Science 2008;21:291-298.

Lanfumey L, Mongeau R, Cohen-Salmon C, Hamon M. Corticosteroidserotonin interactions in the neurobiological mechanisms of stress-related disorders. Neuroscience and Biobehavioral Reviews 2008:32:1174-1184

Lohmann do Brasil. Guia de manejo. Lohmann LSL; 2011. [cited 2016 Jan]. Available from: http://www.Itz.com.br.

Mahmoud KZ, Beck MM, Scheideler SE, Forman MF, Anderson KP, Kachman $\mathrm{SD}$. Acute high environmental temperature and calcium-estrogen relationship in the hen. Poultry Science 1996;75:1555-1562.

Marchant-Forde RM, Fahey AG, Cheng HW. Comparative effects of infrared and one-third hot-blade trimming on beak topography, behavior, and growth. Poultry Science 2008;87:1474-1483.

Marchant-Forde RM, Fahey AG, Cheng HW. Different effects of infrared and one-half hot blade beak trimming on beak topography and growth. Poultry Science 2010;89:2559-2564.

Miller PC, Sunde ML. The effects of precise constant and cyclic environments on shell quality and other lay performance factors with leghorn pullets. Poultry Science 1975;54:36-46.

Petrolli TG, Petrolli OJ, Girardini LK, Zotti MLAN, Baggio RA, Junqueira OM. Effects of laser beak trimming on the development of brown layer pullets. Revista Brasileira de Ciência Avícola 2017; 19:123-128.

Pohle K, Cheng HW. Comparative effects of furnished and battery cages on egg production and physiological parameters in White Leghorn hens. Poultry Science 2009;88:2042-2051.

Prescott NB, Bonser RHC. Beak trimming reduces feeding efficiency of hens. Poultry Science 2004;13:468-471.

Raleigh MJ, McGuire MT, Brammer GL, Pollack DB, Yuwiler A. Serotonergic mechanisms promote dominance acquisition in adult male vervet monkeys. Brain Research 1991;559:181-190.

Rocha JSR, Lara LJC, Baião NC. Produção e bem-estar animal: aspectos éticos e técnicos da produção intensiva de aves. Ciência Veterinária dos Trópicos 2008;11:49-55.

Steklis HD, Raleigh MJ, Kling AS, Tachiki K. Biochemical andhormonal correlates of dominance and social behavior in all-male groups of squirrel monkeys (Saimirisciureus). American Journal of Primatology 1986;11:133-145.

Swayne DE. Diseases of poultry. Developmental, metabolic and other noninfectious disorders. Ames: lowa; 2003.

Tuomisto J, Mannisto P. Neurotransmitter regulation of anterior pituitary hormones. Pharmacology Review 1985;37:249-332.

Xie W, Hou X, Yan F, Sun G, Han R, Kang X. Effect of $\gamma$-aminobutyric acid on growth performance and immune function in chicks under beak trimming stress. Animal Science Journal 2013;84:121-129. 
